\title{
スパイラル筋を使用した RC. 梁のせん断強度 SHEAR STRENGTH OF R/C BEAMS WITH SPIRAL REINFORCEMENT
}

\author{
市之瀬敏勝*，横 尾 慎 一** \\ Toshikatsu ICHINOSE and Shin-ichi YOKOO
}

\begin{abstract}
Based on the upper bound theorem, the shear strength of $\mathrm{R} / \mathrm{C}$ beams with spiral reinforcement is discussed considering its pitch. Three dimensional failure pattern is considered. Conclusions are as follows : (1) Spiral reinforcement is more liable to yield than closed shear reinforcement if their pitch is the same; (2) The shear strength of R/C beams with usual amount of spiral reinforcement is similar to that with the same amount of closed shear reinforcement. The difference appears when the spiral is very sparse and strong : beams with such spiral are stronger than those with closed shear reinforcement of the same pitch and strength.
\end{abstract}

Keywords : reinforced concrete, beam, spiral reinforcement, pitch, shear strength, upper bound theorem 鉄筋コンクリート, 梁, スパイラル筋, 補強筋間隔, せん断強度, 上界定理

1.はじめに

筆者ら ${ }^{11}$ は, 塑性解析の上界定理を用いて, 開鎖型せ ん断補強筋の間隔が RC 梁のせん断強度に及ぼす影響 を調べた。その結果,

（1）せん断補強笳比が同じであっても，補強筋間隔に よってせん断強度は $40 \%$ 程度変動する場合があるこ と,

（2），補強筋間隔によって, $p_{w} \cdot \sigma_{w y} / \sigma_{e} \doteqdot 0.3$

$p_{w}$ : 女ん断補強筋比

$\sigma_{w y}$ : せん断補強筋の降伏強度

$\sigma_{e}:$ コンクリートの有効王縮強度 $\left(=\nu_{0} \sigma_{B}\right)$

程度でもせん断補強筋が降伏しない場合があること，が わかった。本論文では，再び上界定理を用いて，スパイ ラル筋のピッチが RC 梁のせん断強度に及ぼす影響を 調べるまた，閉鎖型補強筋との比較を行う。

\section{2. 解析仮定}

上界定理によるせん断強度算定に当たり, 前報”之同 様に次のことを仮定する。

（1）主筋は十分に強く，部材は曲げ降伏しない。

（2）コンクリートは，図一1のような降伏曲面をもつ 剛塑性材料とする。

（3）スパイラル筋は剛塑性の応力ーひずみ関係をも

つ。

（4）主筋とスパイラル筋のだば作用は無視する。
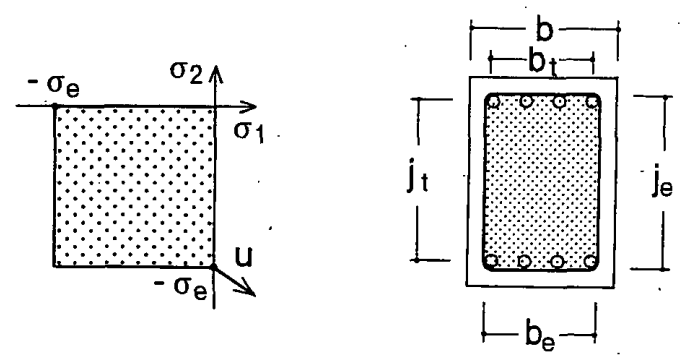

図一1 コンクリートの 降伏曲面

図一2 コンクリートの 有効範囲

（５）部材のコンクリートは，図一2に定義する有効幅 $b_{e}=b_{t}+d_{b}$

$b_{t}:$ 梁幅方向の最外縁主筋重心間距離,

$d_{b}:$ 主筋径

と有効せい

$$
j_{e}=j_{t}+d_{b}
$$

$j_{t}$ : 梁せい方向の最外縁主筋重心間距離で囲まれる 範囲で有効であるとする。

\section{3. スパイラル筋を使用した梁のせん断強度}

主筋が十分強いと仮定しているため, 部材は材軸方向 に伸縮することはない。したがって，主筋は塑性仕事を せず，部材のなす塑性仕事は次式で表される。

$$
W_{e}=W_{c}+W_{s}
$$

$W_{e}$ : せん断力による外部仕事

$W_{c}:$ コンクリートの内部仕事

$W_{s}$ : せん断補強筋の内部仕事
* 名古屋工業大学 助教授・博士 (工学)

** 清水建設・修士 (工学)
Assoc. Prof., Nagoya Institute of Technology, Dr. Eng. Shimizu Corporation, M. Eng. 

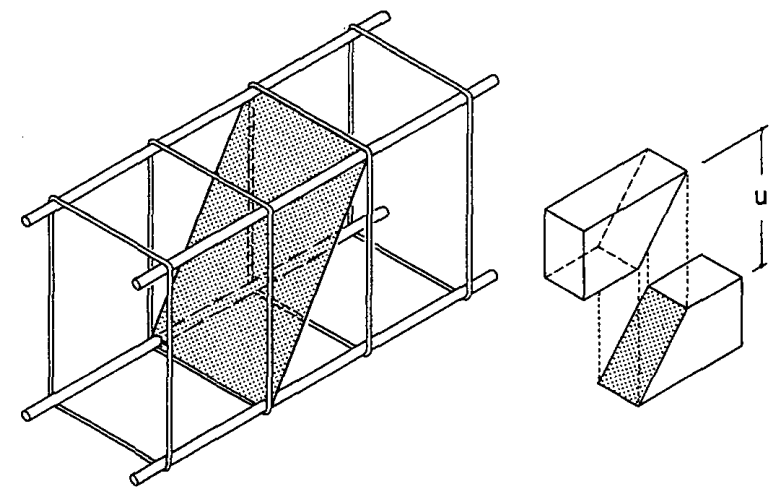

図一3 閉鎖型筋を用いた部材の破壊面（補強筋が降伏しない場 合)
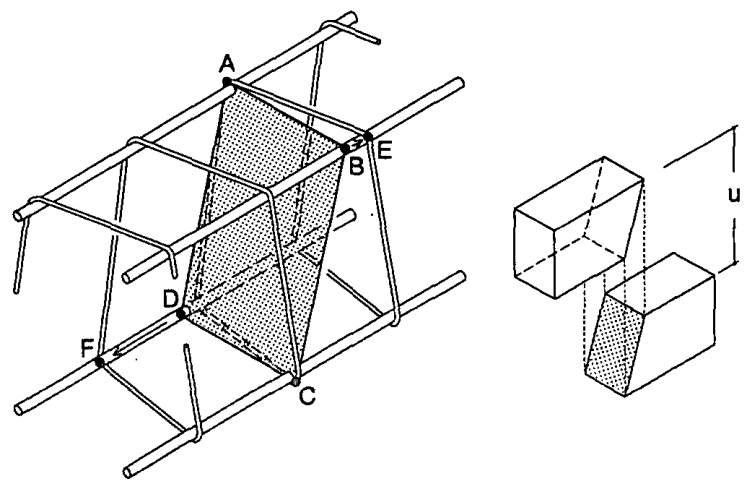

(a) ねじれのない一平面
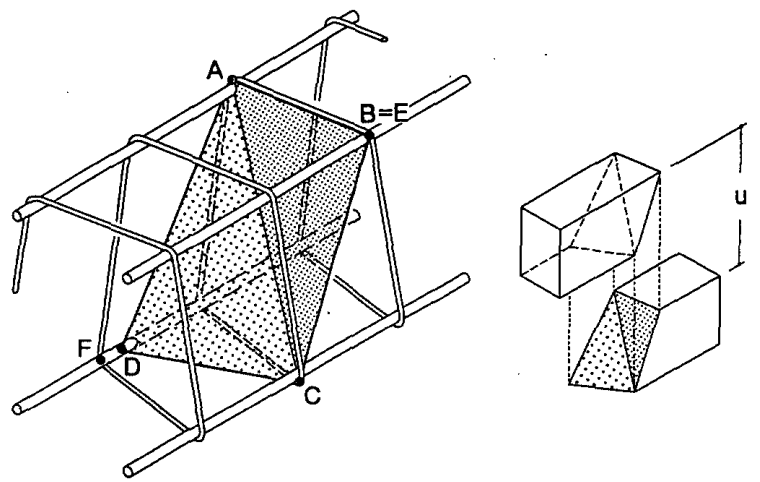

(b) 立体的な二平面

図一4 スパイラル筋を用いた部材の破壊面（補強筋が降伏しな (場合)

上界定理の解は, せん断力による外部仕事 $W_{e}$ が最小 值となるときである。せん断補強筋による内部仕事 $W_{s}$ が同じならば, 破壊面は, コンクリートの内部仕事 $W_{c}$ が小さくなるように生じるはずである。前報”で示した ように，閉鎖型のせん断補強筋を用いた部材のせん断破 壊面は，図一 3 のような単純な平面となる。しかし，ス パイラル筋を用いた場合, 補強筋の挂かり具合がねじれ ているため，破壊面もねじれたものになる可能性がある。

まず，スパイラル筋が降伏しない破壊モード（閉鎖型 の図一 3 に対応）について考えてみる。閉鎖型と同様に， コンクリートの破壊面をねじれのない一平面だと仮定す れば，破壊面は図一-4(a) のような点 A，B，C，Dを

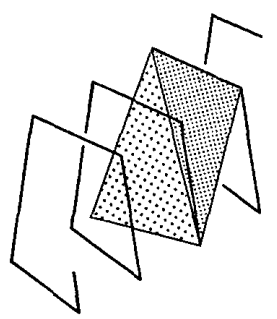

(a) $n=0$

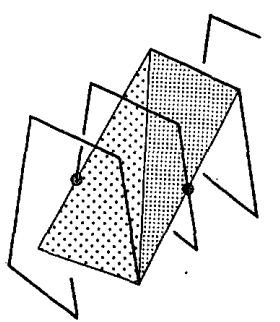

(c) $n=1$

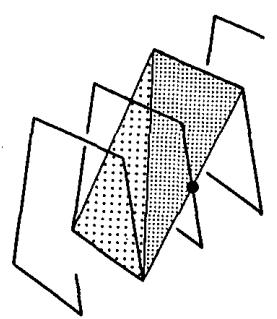

(b) $n=1 / 2$

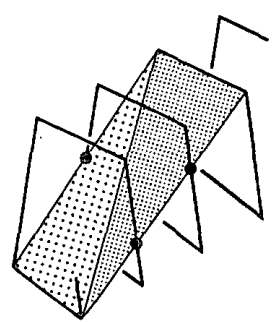

(d) $n=3 / 2$

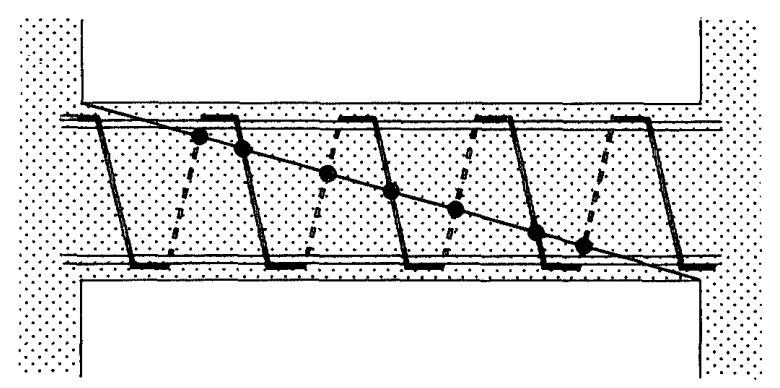

图一6 部材両端を結ぶ破壊面 $(N=7 / 2)$
結ぶ平面となる。点 $\mathrm{A}, \mathrm{C}$ は，主筋とスパイラル筋の 交点に位置する。点 Cにおいて，破壊面がスパイラル 筋の折り曲げ部分を横断しているが，だば作用無視の仮 定により，このスパイラル筋は仕事をしないと考える。

ここで, 点 A， B，C，D は必ずしも一平面上にある 必要はない。コンクリートの内部仕事が小さくなるよう に, 点 $\mathrm{B}$ は点 $\mathrm{E}$ の方向へ, 点 $\mathrm{D}$ は点 $\mathrm{F}$ の方向へ移動 することができる。つまり，図一4(b) のような， $\mathrm{ABC} と \triangle \mathrm{ACD}$ の二平面で構成される破壊面が考えら れる(詳細は付録 1)。ほとんどの場合, 点 $\mathrm{B}$ は点 $\mathrm{E}$ に 一致する。一方, 点 D は補強筋間隔が密な場合にだけ 点 Fに一致する（付録 2$)$ 。図一 $4(\mathrm{~b})$ を $n=0$ の破壊モ一 ドと呼び，図一 $5(\mathrm{a})$ に再揭する。ここで， $n$ は破壊面 を横断するスパイラル筋の組数，すなわち，降伏するス パイラル筋の組数を表す。

スパイラル筋が降伏するモードも同様に定義できる。 片側のスパイラル筋一本(の印)のみが引張降伏するモ一 ドは図一5(b) のようになる。これを， $n=1 / 2$ のモー ドと呼ぶ。また，両側のスパイラル筋 2 本 (1 組) が引 張降伏するモードは図一5(c) のようになる。これを， $n=1$ のモードと呼ぶ。

結局，部材は図一5(a)〜 (d) のような $n=[0,1 / 2 ，$ 


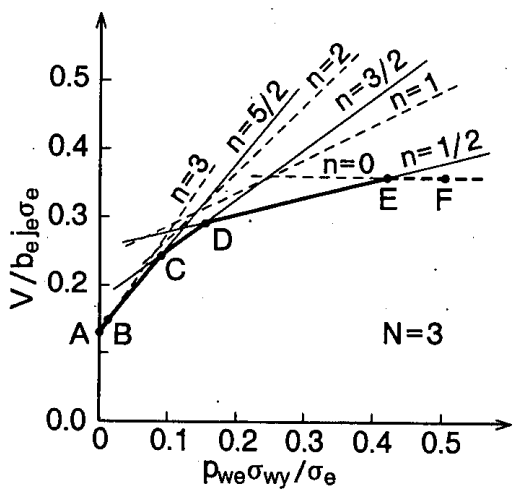

図一7 各破壊モードのせん断強度と補強筋量

$1,3 / 2, \cdots \cdots \cdot]$ の各破壊モードのうち，せん断力による 外部仕事 $W_{e}$ が最小值となるモードでせん断破壊する。 各破壊モードでのせん断強度 $V_{n}$ は, 付録 3 に記述する 強度式によって得られる。ただし, 部材の長さは有限で あるから， $n$ は図一 6 に示す $N$ (部材両端を結ぶ破壊面 と交わるスパイラル筋の組数)を超えることはできない。 スパイラル筋のピッチ $s$ を固定し, 降伏強度 $\sigma_{w y}$ の みを変化させた場合のせん断強度について考えてみる。 $N=3$ の場合について例示すると, 各破壊モードのせん 断強度 $V_{n}$ と補強筋量の関係は, 図一7 のような 4 本の 破線 $(n=0,1,2,3)$ と 3 本の実線 $(n=1 / 2,3 / 2,5 / 2)$ で表される。ただし，横軸のせん断補強筋比 $p_{w e}$ は通 常の定義とは異なり，

$$
p_{w e}=A_{v} /\left(b_{e} \cdot s\right)
$$

$$
\begin{aligned}
A_{v} & \text { : スパイラル筇の一組の断面積 (2 本分) } \\
s & : \text { スパイラル筋のピッチ }
\end{aligned}
$$

とする。部材のせん断強度 $V$ は, 各破壊モードのせん 断強度 $V_{n}$ のうち最小の值を取るので, せん断強度 $V$ 亡補強筋量の関係は, 点 A-B-C-D-E-F を通る折机線 となる。点 $\mathrm{E}$ は，せん断強度が頭打ちとなる点であり， 「補強限界」と呼ぶ。この図で, $n=1,2$ の破線は $\mathrm{A}$ Fの折れ線よりも上側にある。これは， $n=1,2$ のモ一 ドでは破壊が生じないことを意味する。実際，後述の解 析例では，すべて $n=[0,1 / 2,3 / 2, \cdots \cdots \cdot]$ のいずれか の破壊モードで決まり， $n=$ 自然数 $(1,2, \cdots \cdots)$ とな る破壊モードは生じなかった。

\section{4. スパイラル筋と閉鎖型補強筋の比較}

スパイラル筋亡閉鎖型補強筋が, 部材のせん断強度に及 ぼす影響を比較する。

断面形状が $b_{e}=j_{e} / 2$ の部材について, 補強筋間隔 $s$ を $s=0, j_{e} / 5, j_{e} / 2$ としたときのせん断強度と補強筋 量の関係を図一8(a) に示す。ただし, 部材は十分に長 いとする。図中, 実線はスパイラル筋, 破線は閉鎖型補 強筋である。また，スパイラル筋の補強限界を○印で， 閉鎖型筋の補強限界を $\Delta$ 印で示す。図より，閉鎖型を用 いた部材の補強限界より小さなせん断補強レベル（ $\Delta$ の
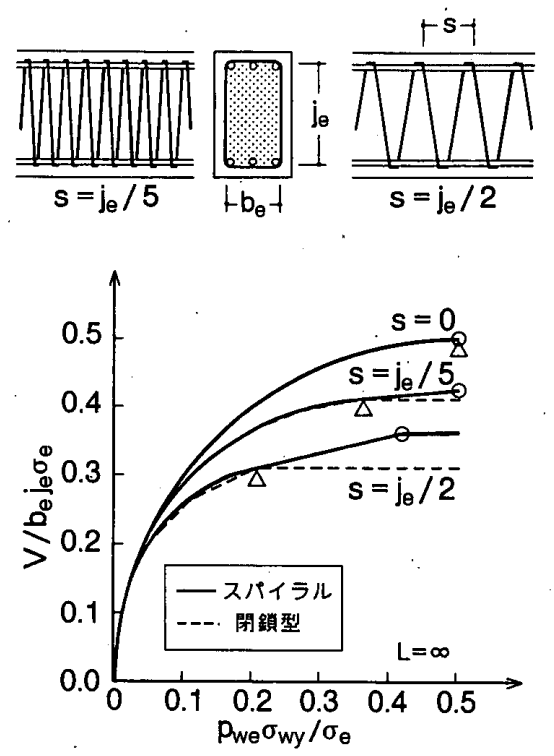

(a) $b_{e}=j_{e} / 2$
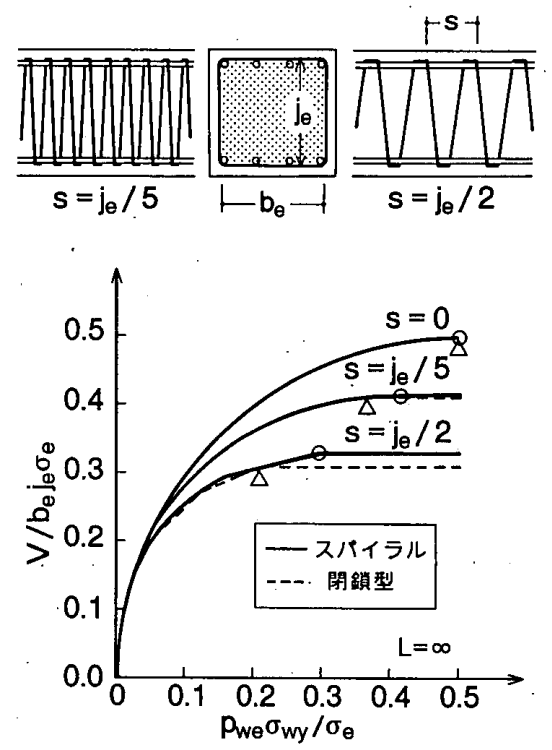

(b) $b_{e}=j_{e}$

図一8 せん断強度と補強筋量

左側）では，スパイラル・閉鎖型のせん断強度はほぼ同 じであると言える。これより大きなせん断補強レベル $(\Delta$ の右側）では，スパイラルが閉鎖型を上回る。断面形状 が $b_{e}=j_{e}$ の部材については, 図一8(b) のように, スパ イラルと閉鎖型で，せん断強度の差は余り見られない。

ここで，閉鎖型筋の補強限界について考えてみると， 例えば $s=j_{e} / 2$ の場合, $p_{w e} \sigma_{w y} \doteqdot 0.2 \sigma_{e}$ であり, 通常の 建物部材に比べるとかなり高いせん断補強レベルであ る。したがって, 通常のせん断補強レベルでは, 閉鎖型 とスパイラルのせん断強度はほぼ等しい，と言える。

せん断補強筋が降伏するための補強筋間隔と補強筋量 の関係を図一9に示す。実線はスパイラル，破線は閉鎖 型の補強限界である。そして, 図のハッチ部分の領域が 閉鎖型補強筋が降伏する条件を表している。スパイラル 筋の補強限界は, 閉鎖型に比べ大きい。すなわち, 補強 


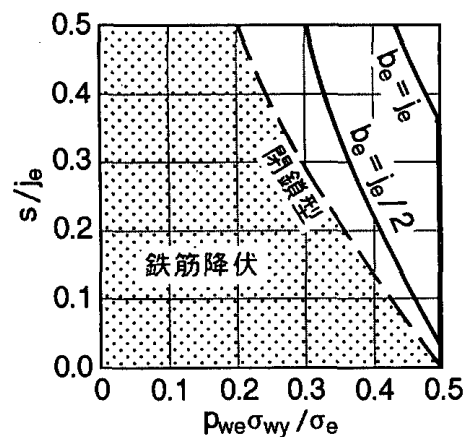

図一9 せん断補強筋が降伏するための補強筋間隔と補強筋量

筋間隔が同じであれば，閉鎖型よりスパイラル筋の方が 降伏しやすい。その差は， $b_{e} / j_{e}$ が大きい部材ほど顕著 である。

\section{5. 破壊モ一ドの検証}

部材の最大せん断強度 $V_{\max }$ を付録 3 の $V_{n}$ に代入す ると, 各破壊モードに対応するコンクリート有効圧縮強 度 $\sigma_{e}, n$ が逆算される。このうち, 最大の $\sigma_{e},{ }_{n}$ が真の 有効圧縮強度 $\sigma_{e}$ である。また, 最大の $\sigma_{e}, n$ を与える破 壊モードが真の破壊モードである。破壊モードが $n=3$ であれば，部材の補強筋は 3 組以上降伏することになる (前報 ${ }^{1}$ 参照)。 $n=1 / 2$ では，片側（図一 5 の手前側） のみの補強筋が降伏し，もう片側は降伏しない。 $n=0$ では，補強筋は 1 組も降伏しないことになる。

部材強度から逆算された破壊モード $n$ と補強筋量と の関係を図一10(a) に示す。解析の対象は，狩野ら ${ }^{2), 3)}$, 渡辺ら ${ }^{4) .5}$ の試験体である。図中, 実験で補強筋が降伏 した試験体を○印, 降伏しなかった試験体を $\Delta$ 印で表す。

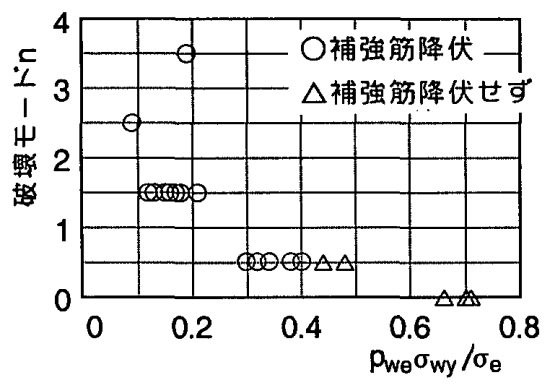

（a） 有効断面による補強筋比 $p_{w e}$

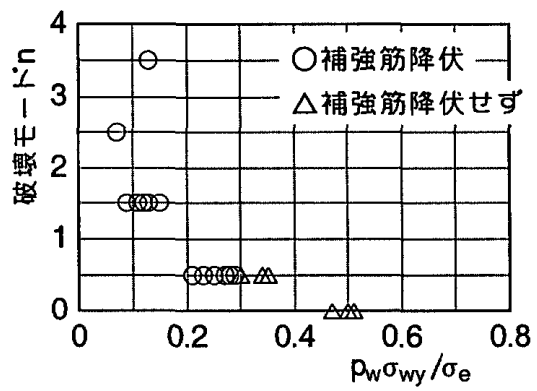

（b）通常の補強筋比 $p_{w}$ による場合

図一10 破壊モード $n$ とせん断補強筋量

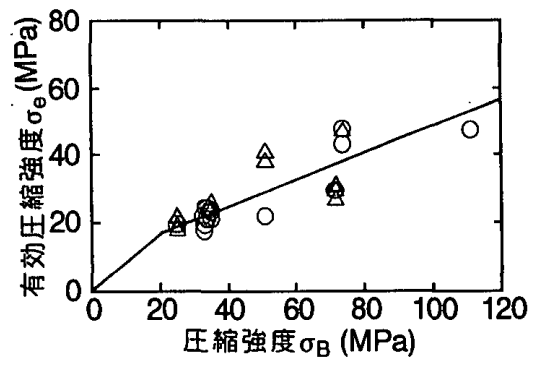

(a) 閉鎖型筋

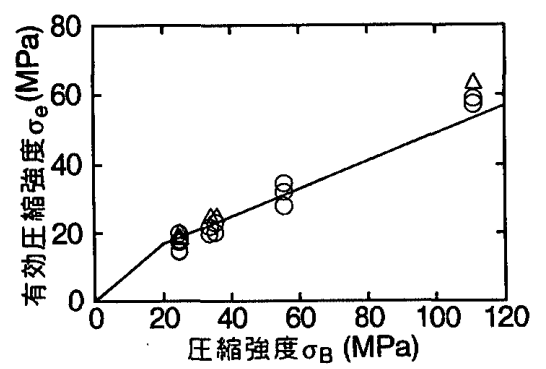

(b) スパイラル筋

図一11 コンクリートの圧縮強度 $\sigma_{B}$ と有効圧縮強度 $\sigma_{e}$

横軸の分母, 有効任縮強度 $\sigma_{e}$ は逆算された值 $\left(\sigma_{e},{ }_{n}\right.$ の 最大值) を使用している。解析データ 21 個のうち, せ ん断補強筋の降伏の有無について実験結果と一致しな かったデータは3 個であった。参考までに, 通常の定義 による補強筋比 $p_{w}$ を用いたグラフを図一10(b) に示す。

\section{6. 有奻圧縮強度の逆算}

狩野 $5^{21,3)}$, 渡辺 $5^{4 \lambda .5)}$, 野口ら ${ }^{6)}$ の実験結果加ら逆算 したコンクリートの有効圧縮強度 $\sigma_{e}$ 亡王縮強度 $\sigma_{B}$ の関 係を図一11(a)（b）に示す。図中, 実験でせん断補強 筋が降伏した試験体を○印，降伏しなかった武験体を 印で表す。この図から，コンクリートの有効圧縮強度 $\sigma_{e}$ を次式のように近似する（図中の太線）。

$\sigma_{B} \leqq 20 \mathrm{MPa}$ のき

$$
\begin{gathered}
\sigma_{e}=0.85 \cdot \sigma_{B} \quad(\mathrm{MPa}) \\
\sigma_{B}>20 \mathrm{MPa} \text { のとき } \\
\sigma_{e}=0.4 \cdot \sigma_{\mathrm{B}}+9 \quad(\mathrm{MP}
\end{gathered}
$$$$
(\mathrm{MPa})
$$

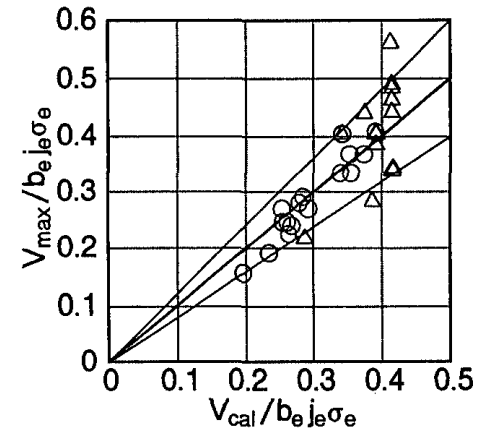

(a) 閉鎖型筋

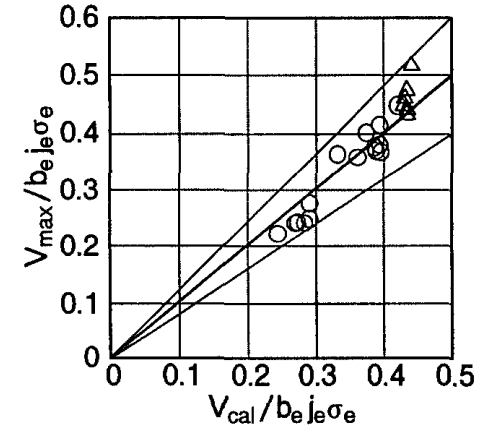

(b) スパイラル筋

図-12 実験との比較 


\section{7. 既往の実験との比較}

コンクリート有効王縮強度の算定に式（6）（7）を 用いて, 狩野ら ${ }^{2) .31}$, 渡辺ら ${ }^{4), 5)}$, 野口ら ${ }^{6)}$ の実験結果之 解析結果を比較する。比較結果を図一12(a) (b) に示す。 図中の記号は図一11 と同じである。 $V_{\max }$ は実験值最大 強度， $V_{c a l}$ はせん断強度計画值である。デー夕数 53 個， 平均值 0.99 , 標準偏差 0.13 であり, 本論文のせん断強 度算定方法は, 実験結果をうまく評価していると言える。

\section{8. 結 論}

立体的な破壊面と補強筋間隔を考慮した上界定理に よってせん断強度を計算した結果，次の結論を得た。

（1）スパイラル筋の補強限界は, 閉鎖型に比べ大きい。 すなわち，補強筋間隔が同じであれば，閉鎖型よりスパ イラル筋の方が降伏しやすい。その差は，せいに比べて 幅の狭い梁ほど顯著である。

（2）閉鎖型筋の補強限界より大きなせん断補強レベル では，スパイラル筋を用いた梁のせん断強度が閉鎖型を 上回る。しかし，通常のせん断補強レベルでは，閉鎖型 とスパイラルのせん断強度はほぼ等しい。したがって, スパイラル筋を用いた梁においても，補強筋間隔の影響 は，閉鎖型と同程度に大きいと言える。

（3）本論文の解析方法によれば，コンクリートの有効 圧縮強度 $\sigma_{e}$ は式（6）（7）で近似できる。

\section{参考文献}

1）市之瀬敏勝, 横尾慎一：せん断補強筋間隔が $\mathrm{RC}$ 梁のせ ん断強度に及ぼす影響，日本建築学会棈造系論文報告集， 1992 年 7 月

2）植松卓二, 高木仁之, 新田隆雄, 奥出久人, 狩野芳一： 高強度せん断補強筋を用いた RC はりのせん断実験（そ の1, その2), 日本建築学会大会学術講演梗概集, pp. $711 \sim 714,1989$

3）狩野芳一，高木仁之，田中礼治，大芳賀義善：高強度せ ん断補強筋を用いた RC はりのせん断実験（その3），日 本建築学会大会学術講演梗概集, pp. 715 716, 1989

4）慶祐一, 榎本浩之, 渡辺史夫, 六車 熙: 高強度コン クリートを用いた梁のせん断強度に関する研究，(その 1 $f_{c}^{\prime}=600 \mathrm{~kg} / \mathrm{cm}^{2}, 800 \mathrm{~kg} / \mathrm{cm}^{2}$ に関する研究), 日本建築 学会大会学術講演梗概集, pp. 269 270, 1991

5）榎本浩之, 慶 祐一, 渡辺史夫, 六車 熙: 高強度コン クリートを用いた梁のせん断強度に関する研究，(その 2 せん断強度の評価), 日本建築学会大会学術講演梗概集, pp. $271 \sim 272,1991$

6）雨宮 篤, 野口 博：超高強度 RC 梁のせん断強度に関 する実験的研究, 日本建築学会大会学術講演梗概集, pp. 273 274, 1991

\section{付録 1 立体破捿面の形状}

本文中では， $n=0$ のモードに関して，付図-1(a)（図一4(b) と同一)のような破壊面が考えられる，と書いた。しかし例えば， 付図一1(b) のように, $\triangle \mathrm{ABD}^{\prime}$ と $\triangle \mathrm{BCD}^{\prime}$ の 2 平面で構成され

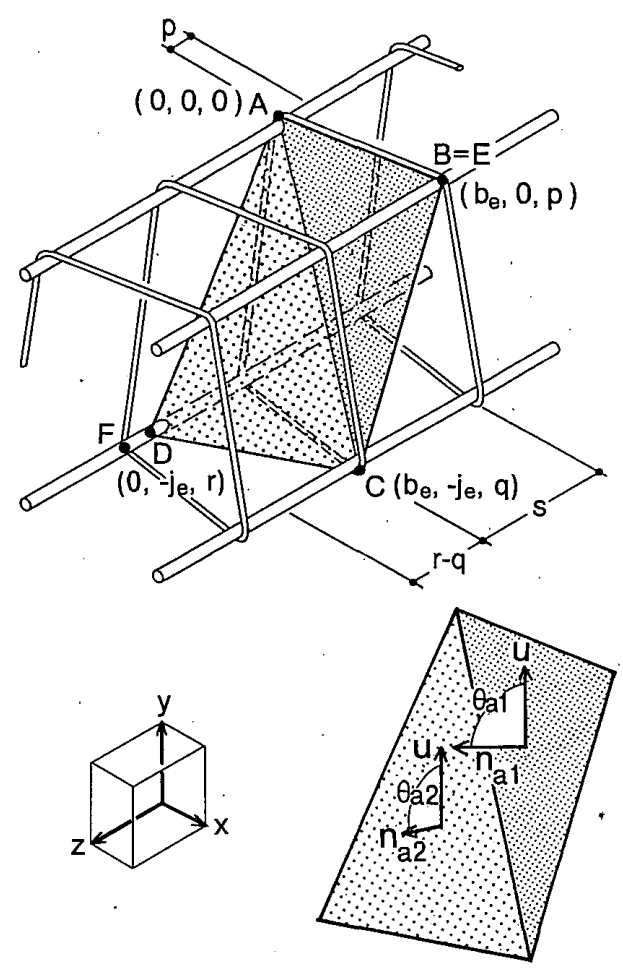

（a）破壊面が $\triangle \mathrm{ABC}$ と $\triangle \mathrm{ACD}$ で構成される場合

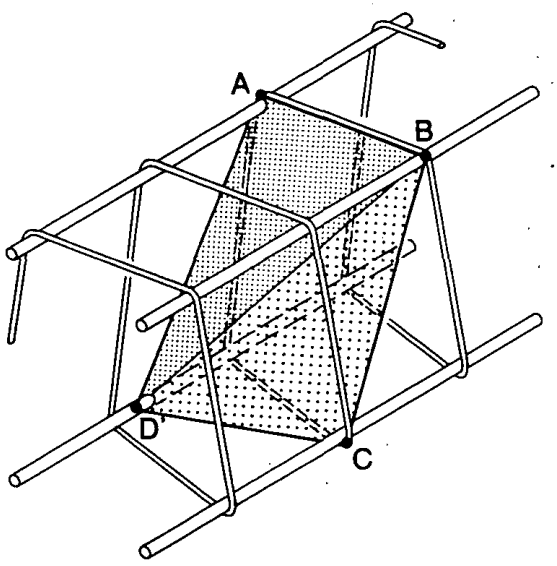

（b）破壊面が $\triangle \mathrm{ABC}^{\prime}$ と $\triangle \mathrm{BCD}$ で構成される場合 付図一1 立体破壊面の座標（スパイラル）

る破壊面も想定可能であるし，その他，より複雑な破壊面も想 定可能である。部材がどの破壊面でせん断破壊するのかは，コ ンクリートの内部仕事 $W_{c}$ を比較すれば良い。結論から先に述 ベよう。付図一1(a) の $W_{c}$ は, 付図一1(b) より必ず低い。し たがって，付図一1(a) の方がより正解に近い。ただし，之の差 は高々 $1 \%$ である（後述）。付図一1(a) の折れ曲がり 2 平面よ りは, 同図の点 $\mathrm{ABCD}$ を通る最小面積の曲面 (石略膜面) の方 が若干小さい $W_{c}$ となる可能性もある。しかし，付図一1(a) (b) の $W_{c}$ の違いが $1 \%$ 未満であることから考えれば; 付図一1(a) の破壊面で実用上は十分であるものと判断できる。

(1) 付図一1(a) のコンクリート内部仕事

立体破壊面の座標を付図一1(a) のように決める。 まず， $\triangle \mathrm{ABC}$ のコンクリート内部仕事を求める。 $\triangle \mathrm{ABC}$ の面積 $A_{a 1}$ は,

$$
A_{a 1}=\frac{1}{2} \sqrt{\left(j_{e} \cdot p\right)^{2}+b_{e}^{2}(q-p)^{2}+\left(b_{e} \cdot j_{e}\right)^{2}}
$$

$\triangle \mathrm{ABC}$ の法線ベクトル（付図一1の $n_{a 1}$ ）は, 


$$
\left[\frac{j_{e} \cdot p}{2 A_{a 1}}, \frac{b_{e}(q-p)}{2 A_{a 1}}, \frac{b_{e} \cdot j_{e}}{2 A_{a 1}}\right]
$$

$\triangle \mathrm{ABC}$ の法線ベクトルが $\mathrm{Y}$ 方向 (変位方向) となす角度 $\theta_{a 1}$ は, 上式ベクトルと $(0,1,0)$ の内積より,

$$
\cos \theta_{a 1}=\frac{b_{e}(q-p)}{2 A_{a 1}}
$$

$\triangle \mathrm{ABC}$ の内部艺事 $W_{c a l}$ は,

$$
W_{c a 1}=\frac{\left(1-\cos \theta_{a 1}\right) \cdot A_{a 1}}{2} \cdot \sigma_{e} \cdot u
$$

となる。次に， $\triangle \mathrm{ACD}$ のコンクリート内部仕事を求める。 $\triangle \mathrm{ABD}$ の面積 $\boldsymbol{A}_{\alpha 2}$ は,

$$
A_{\alpha z}=\frac{1}{2} \sqrt{j_{e}^{2}(r-q)^{5}+\left(b_{e} \cdot r\right)^{2}+\left(b_{e} \cdot j_{e}\right)^{2}}
$$

$\triangle A C D$ の法線ベクトルは、

$$
\left[\frac{j_{e}(r-q)}{2 A_{a 1}}, \frac{b_{e} \cdot r}{2 A_{a 1}}, \frac{b_{e} \cdot j_{e}}{2 A_{a 1}}\right]
$$

$\triangle \mathrm{ACD}$ の法線ベクトルが $\mathrm{Y}$ 方向 (変位方向) となす角度 $\theta_{\alpha 2}$ は, 上式のベクトルと $(0,1 ， 0)$ の内積より，

$$
\cos \theta_{a 2}=\frac{b_{e} \cdot r}{2 A_{a 1}}
$$

$\triangle \mathrm{ACD}$ の内部仕事 $W_{\text {caz }}$ は,

$$
W_{c a z}=\frac{\left(1-\cos \theta_{a 2}\right) \cdot A_{a z}}{2} \cdot \sigma_{e} \cdot u
$$

となる。

したがって,付図一1(a)のコンクリート内部丮事 $W_{c a}$ は式 $(A-4)$

(A-8) の和で与えられ，

$$
W_{c a}=\frac{\left(1-\cos \theta_{a 1}\right) A_{a 1}+\left(1-\cos \theta_{a a}\right) A_{a x}}{2}, \sigma_{e} \cdot u \cdots \cdots(\mathrm{A}-9)
$$

となる。なお, 付図一l(a) の座標点 $p, q, r$ については付録 2 で述べる。

(2) 付図一1(a) (b) のコンクリート内部仕事との此較

付図一1(b) のコンクリート内部仕事 $W_{c b}$ も上と同樣にして 計算できる。 $W_{c b} / W_{c a}$ の比を数值計算により求めたところ,

$$
\begin{aligned}
& 0.1 \leqq \frac{b_{e}}{j_{e}} \leqq 1.0 \\
& 0.01 \leqq \frac{s}{j_{e}} \leqq 1.0
\end{aligned} \mid
$$

の範囲内で, $W_{c b} / W_{c a}=0.99 \sim 1.00$ であった。つまり， $W_{c b}$ は $W_{c a}$ よりも必ず大きいが，その差は $1 \%$ 末満であるという結果 を得た。

\section{付録 2 立体破垻面の座摽}

付図一1(a) の座標值 $p, q, r$ について考える。まず, 点 C は, 点 A から半巻進んだ位置にあることから，スパイラル筋の間隔 を $s$ とすと,

$$
q=s / 2
$$

となる。点 $\mathrm{D}$ は, 2 つの条件から決まる。第 1 に, 式 $(\mathrm{A}-8)$

の $W_{\text {cas }}$ が最小亡なる条件, $d W_{c a z} / d r=0$ より

$$
r_{1}=\frac{j_{e}^{2} q+b_{e}^{2} \sqrt{b_{e}^{2}+j_{e}^{2}+q^{2}}}{b_{e}^{2}+j_{e}^{2}}
$$

を得る。第 2 に, $n=0$,つまり補強筋をまたぐことがないモー ドを前提としているので，点 $\mathrm{F}$ を超えることはないという条件 より,

$$
r_{2}=s+\frac{s \cdot j_{e}}{2\left(b_{e}+j_{e}\right)}
$$

を得る。結局， $r$ は上式のうちの小さい方として，

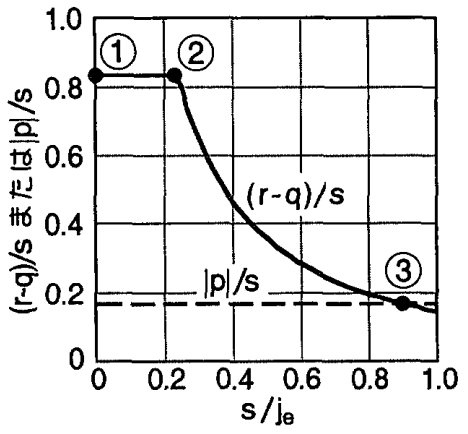

(a) $b_{e}=j_{e} / 2$

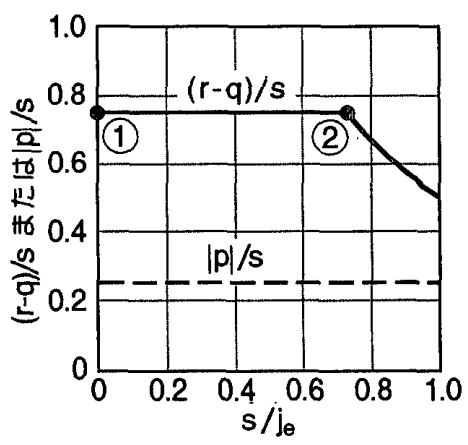

(b) $b_{e}=j_{e}$

付図一2 点 $\mathrm{B}, \mathrm{D}$ が点 $\mathrm{E}, \mathrm{F}$ に一致する条件

$$
r=\min \left(r_{1}, r_{2}\right)
$$

で与えられる。C 点と $\mathrm{D}$ 点の材軸方向の相対距離 $(r-q)$ を 補強筋間隔 $s$ で基準化した結果を, 付図一2(a)（b) に実線で 示す。図中の直線(1)-(2)は, 点 D が点 $\mathrm{F} に 一$ 致したこと,すな わち $r$ が式 (A-12) で决定されたことを表す。図中の(2)から右 下に下がる曲線は, 点 $\mathrm{D}$ が点 $\mathrm{F}$ の内側にあること, すなわち $r$ が式（A-11）で決定されたことを表す。 $b_{e} / j_{e}$ が大きく, $s / j_{e}$ が小さいほど, 点 D が点 Fに一致しやすいことがわかる。

点 $\mathrm{B}$ の座標 $p も$ ，同様にして决定される。すなわち，付図一 1(a) では点 $\mathrm{B}$ がスパイラルのコーナー, 点 $\mathrm{E} に 一$ 致するよう に描いてあるが, 厳密には, まず $d W_{\text {cal }} / d_{p}=0$ より

$$
p_{1}=\frac{b_{e}^{2} q-b_{e}^{2} \sqrt{b_{e}^{2}+j_{e}^{2}+q^{2}}}{b_{e}^{2}+j_{e}^{2}}
$$

を得る。式 $(\mathrm{A}-11)$ と $(\mathrm{A}-14)$ を比べると, $-p_{1}=r_{1}-q$ であ ることがかかる。したがって, $-p_{1} / s$ は, 付図一2(a) (b) の (2)から右下に下がる曲線で表される。次に, 点 B がスパイラル のコーナー, 点 $E$ に一致するという条件から,

$$
p_{2}=-\frac{s \cdot b_{e}}{2\left(b_{e}+j_{e}\right)}
$$

を得る。これは, 付図一2(a)（b) の破線で表される。結局 $p$ は, $p=\min \left(p_{1}, p_{2}\right)$

となる。付図一-2(a) の(3)より右側では $p=p_{1}$ となり点 $\mathrm{B}$ と点 $\mathrm{E}$ とが離れるが, これは $s / j_{e} \geqq 0.9$ というかなり特殊なケース である。それ以外はすべて点 $\mathrm{B}$ と点 $\mathrm{E}$ が一致する。以下の計算 では点 $\mathrm{B}$ と点 $\mathrm{E}$ が一致すると考えて進める。

\section{付録 3 スパイラル筋のせん断強度式}

付図一3(a)（b）の各破壊モード $n$ における座標点 $p, q_{n}, r_{n}$ の值は，付録 2 と同様にして求められ，次のようになる。

$$
p=-\frac{b_{e}}{b_{e}+j_{e}} \cdot \frac{s}{2} \text {. }
$$




$$
\begin{aligned}
& q_{n} \begin{cases}n=0,1,2, \cdots & q_{n}=\frac{2 n+1}{2} s \\
n=\frac{1}{2}, \frac{3}{2}, \frac{5}{2} \cdots & q_{n}=(n+1) s\end{cases} \\
& r_{n}\left(\begin{array}{r}
n=0,1,2, \cdots \quad r_{n}=\min \left(r_{n 1}, r_{n 2}\right) \cdots \cdots \cdots \cdots(\mathrm{A}-21) \\
\text { ただし, } r_{n 1}=\frac{j_{e}^{2} \cdot q_{n}+b_{e}^{2} \sqrt{b_{e}^{2}+j_{e}^{2}+q_{n}^{2}}}{b_{e}^{2}+j_{e}^{2}} \cdots \cdots \cdots(\mathrm{A}-22) \\
r_{n 2}=\left\{2(n+1)+\frac{j_{e}}{b_{e}+j_{e}}\right\} \cdot \frac{s}{2} \cdots \cdots \cdots \cdots(\mathrm{A}-23) \\
n=\frac{1}{2}, \frac{3}{2}, \frac{5}{2}, \cdots \quad r_{n}=\left(2 n+1+\frac{j_{e}}{b_{e}+j_{e}}\right) \cdot \frac{s}{2} \cdots(\mathrm{A}-24)
\end{array}\right.
\end{aligned}
$$

$\triangle \mathrm{ABC}$ のコンクリートの内部仕事 $W_{1, n}$ は,

$$
W_{1, n}=\frac{\sqrt{\left(j_{e} \cdot p\right)^{2}+\left(b_{e} \cdot j_{e}\right)^{2}+b_{e}^{2}\left(p-q_{n}\right)^{2}}-b_{e}\left(q_{n}-p\right)}{4} \cdot \sigma_{e} \cdot u
$$

$\triangle \mathrm{ACD}$ のコンクリートの内部仕事 $W_{2, n}$ は,

$$
W_{2, n}=\frac{\sqrt{\left(b_{e}^{2}+j_{e}^{2}\right) r_{n}^{2}-2 q_{n} r_{n} j_{e}^{2}+\left(q_{n}^{2}+b_{e}^{2}\right) j_{e}^{2}}-b_{e} \cdot r_{n}}{4} \cdot \sigma_{e} \cdot u
$$

破壊面のコンクリートの内部仕事 $W_{c}, n$ は,

$$
W_{c, n}=W_{1, n}+W_{2, n}
$$

破壊面を横断するスパイラル筋の内部仕事 $W_{s, n}$ は,

$$
W_{s, n}=\left[n \cdot A_{v} \cdot \sigma_{w y} \cdot \sin \alpha\right] u
$$

ただし，角度 $\alpha$ は，材軸とスパイラル筋のなす角度で，次式で 与えられる。

$$
\sin \alpha=\frac{2\left(b_{e}+j_{e}\right)}{\sqrt{4\left(b_{e}+j_{e}\right)^{2}+s^{2}}}
$$

各破壊モード $n$ におけるせん断力の外部仕事 $W_{e, n}$ は,

$$
W_{e, n}=u \cdot V_{n}=W_{c, n}+W_{s, n}
$$

となる。部材のせん断強度 $V$ は各破壊モード $n$ のせん断強度 $V_{n}$ の最小値をとる。

(1992 年 4 月 10 日原稿受理, 1992 年 8 月 4 日採用決定) 